\title{
Investigation of anilox roller cell clogging
}

\section{ABSTRACT}

One vital component in the flexo inking system of high-line screen engraving technologies is anilox rollers. These deliver a precise and consistent amount of ink during the process of flexography, making it possible to produce high-resolution prints of exceptional quality. However, as print quality continues to improve, printing houses are experiencing more frequent problems with anilox rollers, such that ink transfer during printing operations is being unpredictably reduced. Due to the lack of research into anilox rollers there is insufficient objective information on how to maintain them at peak performance and condition. This study investigates the clogging of anilox roller cells (without assessing cell wear) in a number of printing houses in the Baltic States. Cell clogging of anilox rollers was determined depending on cell size, ink type and washing method.

\section{KEY WORDS}

Anilox roller, flexography, cells engraving, ink transfer, clogging

\section{Arnas Savickas \\ Rimantas Stonkus \\ Eugenijus Jurkonis}

Vilnius Gediminas Technical

University, Faculty of Mechanics, Department of Mechatronics, Robotics and Digital Manufacturing, Vilnius, Lithuania

\author{
Corresponding author: \\ Eugenijus Jurkonis \\ e-mail: \\ eug.jurkonis@gmail.com
}

First recieved: 14.7.2020.

Accepted: 2.9.2020.

\section{Introduction}

Flexographic printing is one of the growing printing technologies, ideal for printing on very different substrates such as paper, cardboard, foils, and film, and is mainly used in the packaging industry (FTA, 2014). Numerous studies have been conducted in this area analyzing the quality of prints and their effect on ink composition, contact pressure between the printing form and the substrate (Johnson, 2008), and deformation of the printing form (Bould, Claypole \& Bohan, 2004). Slightly less research is related to the most important component of the inking system of flexographic machines, the anilox roller. Notwithstanding, there are studies evaluating the effect of pressure changes on print quality depending on the parameters of the anilox rollers (Bould et al., 2011), the rate of clogging of anilox rollers (Khmiliarchuk
\& Shubko, 2016), and differences in the volume measurement of anilox rollers (Provident Group Ltd \& Troika Group Ltd, 2008).

Among other factors, print quality is greatly affected by the condition of the anilox rollers, and this depends on their operating conditions. Where maintenance of the rollers is deficient, there is an increased probability that the cells will become clogged more quickly. This results in wear in the cell walls and reduced transfer of ink, resulting in lower optical density of the prints and poor quality of output.

The aim of this study was to investigate the condition of anilox rollers used in flexographic printing in printing houses in the Baltic States, and to evaluate factors influencing their condition. 
Hypotheses:

- Higher line screen anilox rollers tend to become dirtier than in the case of lower screen rollers.

- Cells with a higher cell depth to opening ratio tend to become more clogged than cells with a lower depth to opening ratio.

Any change in the condition of anilox rollers is directly related to a reduction in the amount of ink transferred, hence the amount of transferred ink decreases due to cell clogging or wear of cell walls.

Cell clogging is affected by a number of factors, including: the type of ink (faster drying ink can dry faster in cells); washing frequency (infrequent washing allows the ink to dry in the cells more often); washing method (inefficient washing does not completely clean the ink from the cells); the service life of the anilox roller (more frequent use leads to more frequent ink changes and clogging); and line screen (higher line screen anilox roller cells are smaller, making it more difficult to wash).

However, manufacturers alone cannot be held responsible for the amount of ink transferred by anilox rollers (Claypole \& Cox, 2010). Until there is an established international standard for how such measurement should be performed, and what instruments should be used, the ink transfer parameters of each manufacturer will remain very different (Provident Group Ltd \& Troika Group Ltd, 2008).

Previous studies confirm that in order to maintain optimal print quality, ink transfer inspection procedures need to be followed by the printing house. This would check not only the condition of the rollers after use, but also compare newly manufactured anilox rollers.

\section{Methods}

The study presented herein used AniCAM (Troika Systems Limited, UK) three-dimensional optical microscope with AniloxQC software to measure anilox rollers.

The parameters of anilox rollers that are investigated: changes in ink transferring from nominal value; line screen value; level of clogging; cell to wall widths and cell depth to opening ratios; the conditions of use of anilox rollers.

\section{Anilox roller condition evaluation parameters}

\section{Level of cell clogging}

The objective assessment of the clogging of anilox rollers provided data by which we could statistically estimate the clogging, and identify dependencies on other parameters. For this purpose, a methodology for assessing the level of clogging was developed, in which the degree of clogging was assessed at five levels, where 1 was completely clean cells and 5 were completely clogged cells (Table 1).

\section{Change in ink transfer}

Each anilox roller is measured at three locations, near the ends and in the middle. From the three measurements, the average is derived, which is considered to be the real average transfer of anilox roller ink. This measured parameter can be compared to the nominal transmission. Because a large number of anilox rollers with different ink transfer values are analyzed, the relative change calculated by the formula is more suitable for purposes of comparison:

change in ink transfer $=\left(\frac{\text { measured ink transfer }}{\text { nominal ink transfer }}-1\right) \cdot 100 \%$

The calculated relative change shows how much the measured average ink transfer value differs from the nominal parameter (manufacturer's information). A negative value means that the measured ink transfer value is less than the nominal parameter, and a positive value means that it is higher.

\section{Cell depth to opening ratio}

The ink transfer parameter of the anilox roller directly depends on the depth and opening of the cells engraved on it. To increase ink transfer, at least one of the cell's sizes must be increased.

If the opening (width) of the cells is increased, then fewer cells occupy the surface of the roller, thus reducing the line screen. Since the printing house often needs to print with printing forms with very fine raster dots, there is a limit to how much the line screen of the anilox roller can be reduced. While there are various theories about combining the line screen of the printing form and the anilox roller, the general rule is that the anilox roller line screen should be four times larger than the line screen of the printing form. Once the maximum cell width is set, only the cell depth can be increased. In theory, cell depth is limited only by the layer of ceramic on the anilox roller, however the depth to opening ratio recommended by the manufacturers should be followed- usually about 0.3 (Poppen, 2020; Harper, 2020). Problems can result in the case of too high a cell depth to opening ratio, such as 0.7 , or even 1.1. These are:

- The capillary phenomena which results in a transfer of a smaller amount of ink.

- Cells become more difficult to clean and untreated ink eventually dries out.

- It is difficult to engrave cells with uniform parameters. 


\section{Table 1}

Types of clogging levels with comments

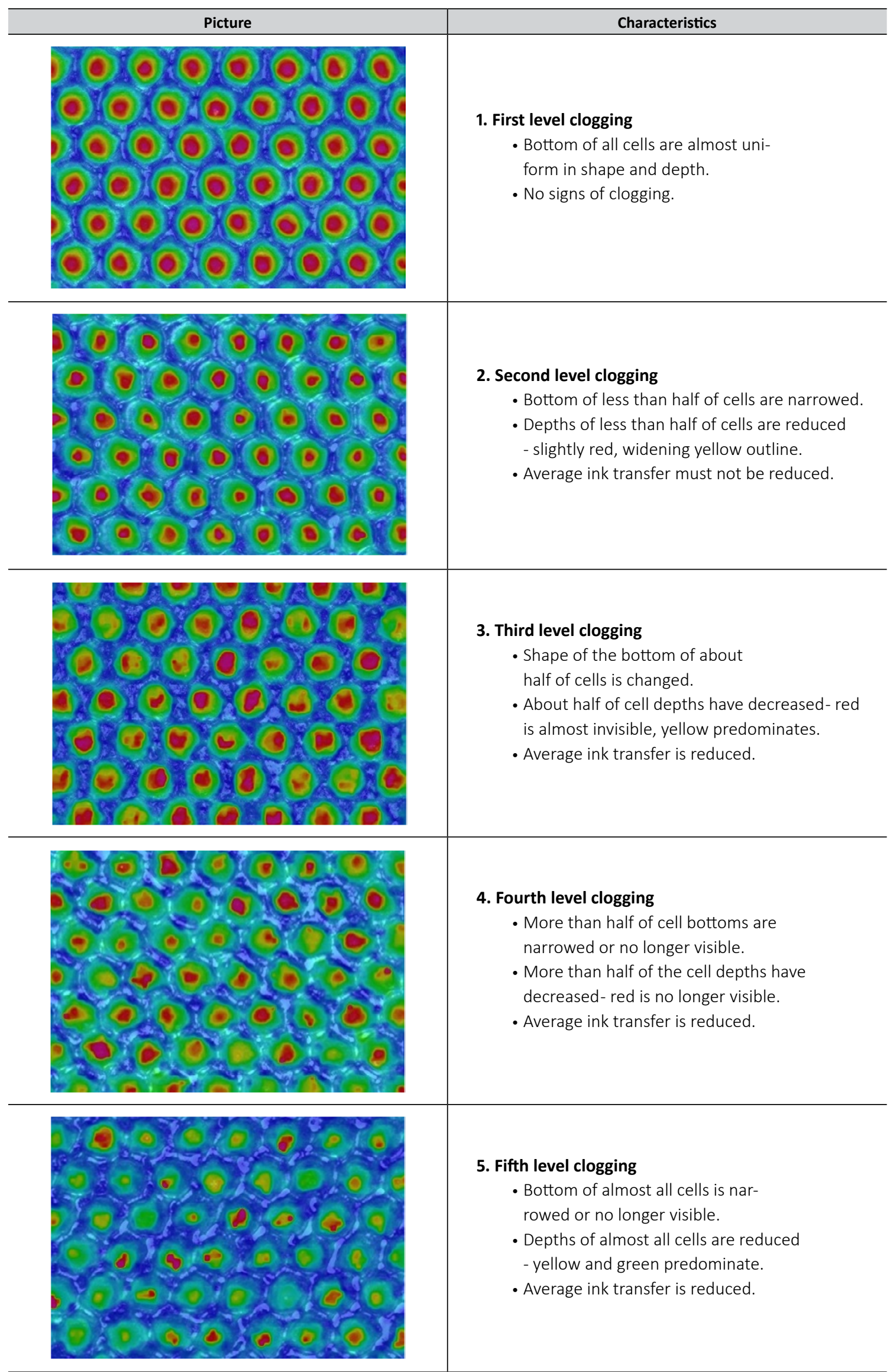


When a depth to opening ratio is less than recommended, such as 0.23 cells, it can cause other problems:

- The surface of the cells become uneven and rough. - Ink may start to dry in the cells during printing.

The given cell depth to opening ratio recommendations are generally valid for hexagonal $60^{\circ}$ engraving. To use a higher ratio, the manufacturers of anilox rollers offer engraving of elongated hexagonal cells at an angle of $75^{\circ}$. In the direction of rotation of the roller, the opening of the cells can be 1.5 to 3 times longer and due to the reduced capillary force, a larger amount of ink is transferred in the cell.

\section{Results and discussion}

\section{Measurement statistics}

The study measured 326 anilox rollers which were obtained from 16 printing houses in the three Baltic countries of Lithuania, Latvia and Estonia. Rollers produced by 9 different manufacturers from the USA, Italy, Germany, the United Kingdom, Poland and the Netherlands were measured. Measured anilox rollers are used in 28 different printing machines from 14 manufacturers.

Of the anilox rollers selected for the study, the largest measurements were made from Sandon (UK) (70 rollers), followed by Zecher GmbH (Germany) (64 rollers). The least measured was Tewex (Poland) with 14 rollers, although this manufacturer no longer supplies the European market, followed by Praxair (USA) with 18 rollers. Out of a total of 326 measurements, 12 roller manufacturers could not be identified due to worn identification marks.

Most of the anilox rollers were engraved with a standard $60^{\circ}$ angle ( 255 rollers out of 326 ). The second largest category, the $75^{\circ}$ engraving angle, consisted of 55 rollers. About $30 \%$ of printing houses in the Baltic States are included in the research data. Figure 1 shows the anilox line screen distribution of all anilox rollers (dividing all rollers into ranges of $100 \mathrm{~L} / \mathrm{cm}$ ).

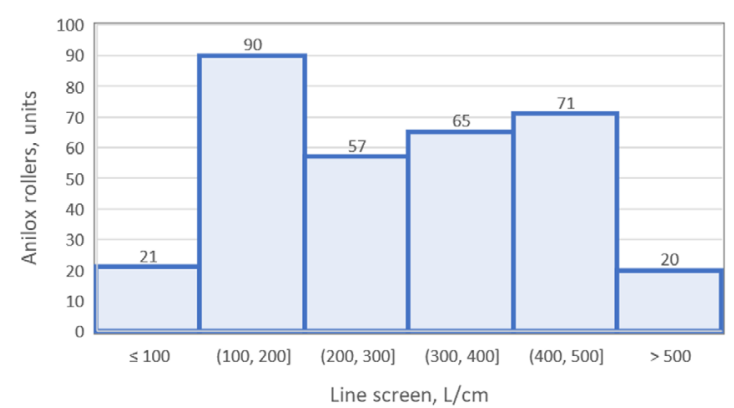

» Figure 1: Line screen distribution of anilox rollers
Figure 2 shows the distribution of anilox rollers according to the change in their measured ink transfer from the declared one. $26.6 \%$ of all measured rollers fall in the range $(-5.0 ; 5.0]$. Since the manufacturers of anilox rollers also apply a range of $\pm 5 \%$ ink transfer when engraving the surface and such results are considered to be the best. $26.3 \%$ of rollers fall within the range $(-15.0 ;-5.0]$, which is a satisfactory result.

Surprisingly, printing houses still use anilox rollers with a reduction in ink transfer of more than $35 \%$, which represents $5.7 \%$ of all rollers measured. Also, as many as $2.5 \%$ of rollers have a measured ink transfer increase of more than $25 \%$, and one of these rollers exceeds $45 \%$. A difference of this size from the declared value can cause difficulties in properly selecting the anilox roller for the printing process, as the print can produce much higher color intensities than expected.

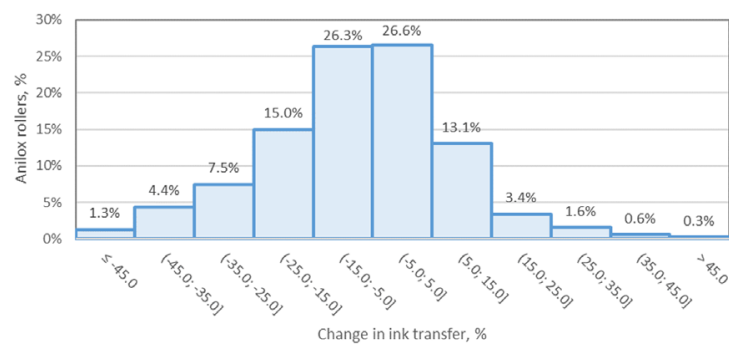
» Figure 2: Distribution of anilox rollers according to the
change in ink transfer

The described distribution of the cell depth to opening ratio according to the engraving angle is also confirmed by the data of anilox rollers measured during the study, which is shown in Figure 3. As can be seen, the largest part of the anilox rollers engraved at an angle of $60^{\circ}$, $32.3 \%$ of the rollers, falls within the range of $(0.4 ; 0.5$ ] cell depth to opening ratio, while the largest part of the anilox rollers engraved at an angle of $75^{\circ}-29.1 \%$ fall into a slightly larger range of $(0.5 ; 0.6$ ] cell depth to opening ratio. It is also worth noting that the cell depth to opening ratio of anilox rollers engraved at an angle of $60^{\circ}$ is located from $(0.1 ; 1.0]$ and $75^{\circ}$ to the longer range $(0.2$; 1.3], which shows the versatility of the extended cellsthe same line screen can be given at both very low and very high ink transfer.

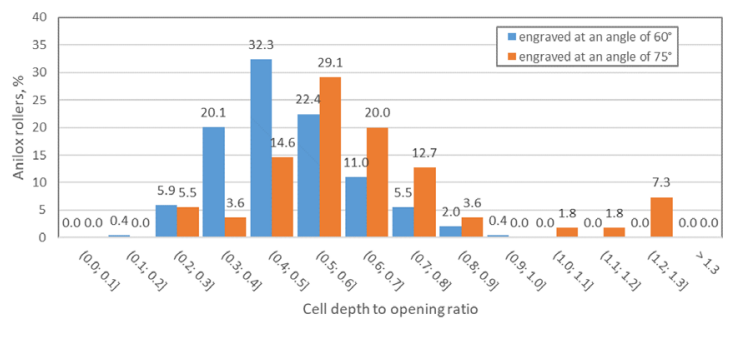

» Figure 3: Distribution of anilox rollers by cell depth to opening ratio 
Although the condition of anilox rollers was found to be affected by both service life and washing frequency, the study failed to collect enough accurate data to make some comparisons. It is not possible to determine the exact service life of each roller; such information was not collected at any printing house. Also, each anilox roller is used for different jobs and even custom-made rollers ultimately maintain quality for a different amount of time. It is also difficult to calculate the frequency of washing of anilox rollers- due to the limited number of rollers that can be washed at one time, some rollers are washed immediately after being removed from the printing machine, and others only after one or two washing cycles, each lasting about 30 minutes.

\section{Clogging of anilox rollers}

\section{Clogging distribution of anilox rollers}

All anilox rollers were visually assessed and assigned a level of clogging from 1 to 5 . As can be seen in Figure 4 , most of the measured rollers are of the second level of clogging- 83 units, and at least of the fifth level- 38 units. It can be seen that there are more than half of the rollers with a clogging level of 3 and higher. This means that most rollers are either cleaned infrequently or poorly cleaned.

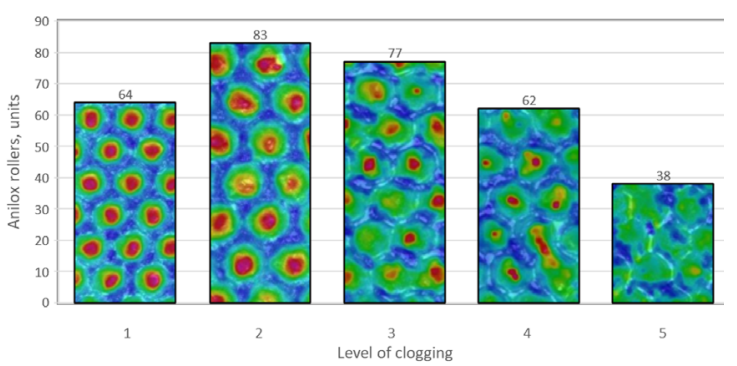

» Figure 4: Distribution of anilox rollers according to the level of clogging

\section{Dependence of clogging on cell size}

In practice, larger line screen anilox rollers are generally considered to be more difficult to clean. Figure 5 shows the line screen distribution of anilox rollers according to the level of clogging. The graph shows that the higher the line screen of the rollers, the higher the level of clogging- the averages increase from $169 \mathrm{~L} / \mathrm{cm}$ at the first level of clogging to $428 \mathrm{~L} / \mathrm{cm}$ at the fifth level. It can also be observed that the higher the level of clogging, the higher the minimum line screen of the anilox rollers entering it. This may mean that the rollers of the lowest liners are more difficult to clog-for example, 21 anilox rollers with a liner not exceeding $100 \mathrm{~L} / \mathrm{cm}$ were measured (see Figure 1) and none of the clogging levels were higher than 3. Meanwhile, the maximum line screen at each level of clogging is $580 \mathrm{~L} / \mathrm{cm}$, except at the first level $480 \mathrm{~L} /$ $\mathrm{cm}$. Thus, it can be seen that even very high line screen rollers can be maintained in conditions where there is a state of unclogging or a state of nearly unclogging.

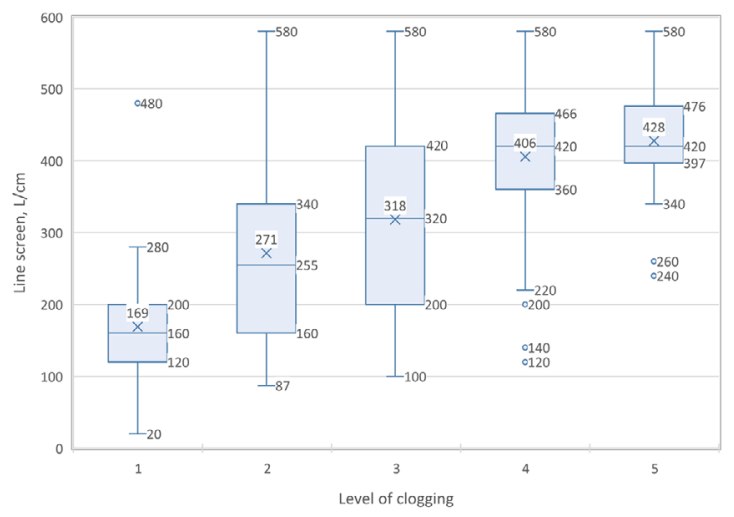

» Figure 5: Line screen distribution of anilox rollers according to the level of clogging

As mentioned earlier, one of the causes of cell clogging is too high a ratio of cell depth to opening, making it more difficult to clean the ink, which then dries more easily if it is not cleaned. In order to compare graphs of line screen and cell depth to opening ratios, it is necessary to analyze uniform engraving rollers. Figure 6 shows the line screen distribution of anilox rollers engraved at an angle of only $60^{\circ}$ according to the level of clogging. The same trend is observed here as in Figure 5- as the level of pollution increases, the average line screen also increases. Thus, the hypothesis that the larger the line screen, the more clogged anilox rollers tend to become is confirmed.

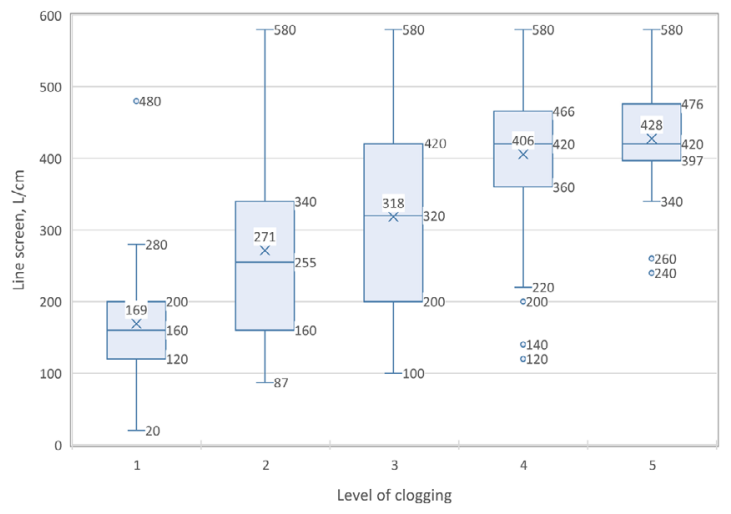

» Figure 6: Line screen distribution of anilox rollers according to the level of clogging (Rollers with $60^{\circ}$ angle engraving only)

Also, with the exception of anilox rollers engraved at an angle of only $60^{\circ}$, Figure 7 shows a graph of the dependence of the cell depth to opening ratio on the line screen of roller. As can be seen, as the engraving line screen increases, the average cell depth to opening ratio also increases. This increase can be explained by the need to maintain high ink transfer when a high line screen anilox roller is used for printing, which is also used for a high-line screen printing form. 


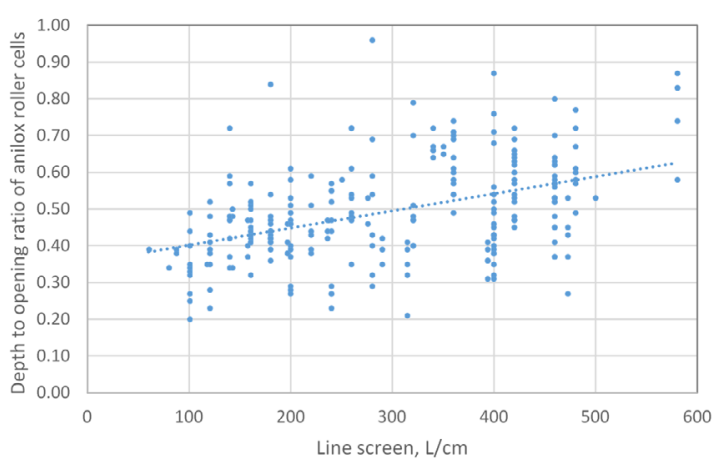

» Figure 7: Dependence of the depth to opening ratio of anilox roller cells on the line screen (Rollers with $60^{\circ}$ angle engraving only)

The previously established high-line screen and clogging correlation suggests that the cell depth to opening ratio can be directly related to the level of clogging. However, as shown in Figure 8, no marked increase in the depth to opening ratio is observed as the level of clogging increases. This may be due to the fact that the measurements do not contain data on the parameters of the cells when the anilox roller was just manufactured and not yet clogged. When the roller is dirty, its average cell depth decreases and the ratio of cell depth to opening decreases directly. From a relatively horizontal line through the averages of the clogging levels (Figure 8), it can be assumed that the anilox rollers become, on average, clogged to a level where their cell depth to opening ratio decreases to 0.48-0.51. At the same time, the cell becomes easier to wash out and there is a slowing down in clogging.

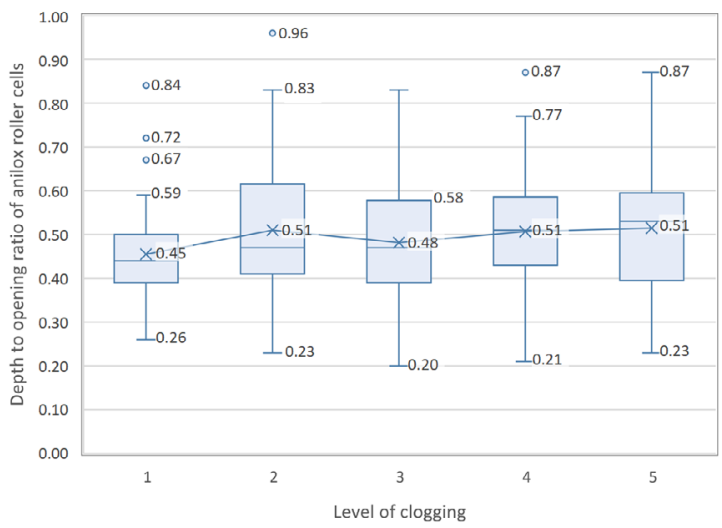

» Figure 8: Arrangement of depth to opening ratio of anilox roller cells according to the level of clogging (Rollers with $60^{\circ}$ angle engraving only)

\section{Conclusions}

Investigations of the state of clogging of anilox rollers used in flexography in printing houses in the Baltic States lead to conclusions:
1. $26.6 \%$ of analyzed anilox rollers ink transfer changes are within $\pm 5 \%$ (recommended by anilox roller manufacturers). $13.2 \%$ of the anilox roller ink transfer change was less than-35\%, and $2.5 \%$ of the roller ink transfer change was more than $+25 \%$. Large discrepancies in ink transfer from the ratings indicate potential difficulties for the print house in selecting the right anilox roller for each print job.

2. 177 of 324 anilox rollers had a clogging level of 3 or higher. This means that more than half of the anilox rollers in printing houses are not properly washed.

3. The hypothesis that larger line screen anilox rollers tend to become more clogged is confirmed. The average linearity in the first level pollution segment is $169 \mathrm{~L} / \mathrm{cm}$ and increases with an increasing pollution level until it reaches an average linearity of $428 \mathrm{~L} / \mathrm{cm}$ in the fifth level pollution segment.

4. The hypothesis that cells with a higher cell depth to opening ratio tend to become more clogged than a lower cell ratio cannot be tested due to the lack of data. Since both clean and already clogged anilox rollers were studied, after adjusting the data for the level of clogging, an increase in the average cell depth to opening ratio was observed with increasing clogging level of 0.45 at the first clogging level and 0.62 at the fifth clogging level.

\section{References}

Bould, D. C., Claypole, T. C. \& Bohan, M. F. J. (2004) An investigation into plate deformation in flexographic printing. Proceedings of the Institution of Mechanical Engineers, Part B: Journal of Engineering Manufacture. 218 (11), 1499-1511. doi: $10.1243 / 0954405042418428$.

Bould, D. C., Hamblyn, S. M., Gethin, D. T. and Claypole, T. C. (2011) Effect of impression pressure and anilox specification on solid and halftone density. Proceedings of the Institution of Mechanical Engineers, Part B: Journal of Engineering Manufacture. 225 (5), 699-709. doi: 10.1177/2041297510394072.

Claypole, T., Cox, K. (2010) Measuring Anilox Volume: FQC's Gauge R\&R Study. New York, FTA. Available from: https://www.flexography.org/industry-news/ measuring-anilox-volume-fqc-gauge-rr-study [Accessed: 20th June 2020].

FTA (2014) Flexography: Principles and Practices. 6th ed. New York, Foundation of Flexographic Technical Association. p. 612.

Harper (2020) Specifying the Right Anilox Roll. Charlotte, Harper Anilox \& Coating Division. Available from: http://www.harperimage.com/AniloxRolls/ Anilox-Guides/Specifying-the-Right-Anilox [Accessed: 25th June 2020].

Johnson, J. (2008) Aspects of Flexographic Print Quality and Relationship to some Printing Parameters. PhD thesis. Karlstad University.

Khmiliarchuk, O. I. \& Shubko, Y. S. (2016) Modeling of Anilox Cells Pollution Process. Kiev, ELAKPI. Available from: https://ela.kpi.ua/handle/123456789/16538 [Accessed: 25th June 2020]. 
Poppen, M. (2020) The Secret to Print Consistency: Maintaining Anilox Roll Volume. New York, FTA. Available from: https://www.flexography.org/industry-news/ print-consistency-maintain-anilox-roll-volume [Accessed: 20th June 2020].

Provident Group Ltd \& Troika Group Ltd (2008) Do you really know the volume of your Anilox rolls?. Appleton, Provident LLC. Available from: https://www. providentgrp.com/do-you-really-know-the-volume-of-your-anilox-rolls [Accessed: 20th June 2020].

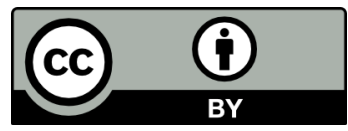

(C) 2020 Authors. Published by the University of Novi Sad, Faculty of Technical Sciences, Department of Graphic Engineering and Design. This article is an open access article distributed under the terms and conditions of the Creative Commons Attribution license 3.0 Serbia (http://creativecommons.org/licenses/by/3.0/rs/). 